Article

\title{
Analysis of Meteorological Conditions on Riverbed Dust Aerosol in Taiwan
}

\author{
Fujung Tsai *, Wan-Chi Yao and Ming-Lung Lin
}

Citation: Tsai, F.; Yao, W.-C.; Lin, M.-L. Analysis of Meteorological Conditions on Riverbed Dust Aerosol in Taiwan. Atmosphere 2022, 13, 106 https://doi.org/10.3390/ atmos13010106

Academic Editor: Jorge Pey

Received: 15 November 2021

Accepted: 5 January 2022

Published: 10 January 2022

Publisher's Note: MDPI stays neutral with regard to jurisdictional claims in published maps and institutional affiliations.

Copyright: (c) 2022 by the authors. Licensee MDPI, Basel, Switzerland. This article is an open access article distributed under the terms and conditions of the Creative Commons Attribution (CC BY) license (https:// creativecommons.org/licenses/by/ $4.0 /)$.
Department of Marine Environmental Informatics, National Taiwan Ocean University, Keelung 202, Taiwan; 4034E019@mail.ntou.edu.tw (W.-C.Y.); 4034E007@mail.ntou.edu.tw (M.-L.L.)

* Correspondence: fujung@email.ntou.edu.tw

\begin{abstract}
Extremely high concentrations of dust particles are occasionally generated from the riverbeds of Taiwan, affecting the visibility and traffic safety of the local and nearby areas. The condition is most severe during the winter monsoon when surface wind is strong. This study analyzes the concentration of particulate matter of $10 \mu \mathrm{m}$ or less $\left(\mathrm{PM}_{10}\right)$, wind direction, wind speed, temperature, and humidity of riverbed stations adjacent to the Daan, Dajia, Dadu, Zhuoshui, and Beinan Rivers in Taiwan for a period of two years. The weather conditions that cause the high concentration of $\mathrm{PM}_{10}$ are classified into typhoon and non-typhoon types, and the latter type is further classified into three stages: ahead of front, ahead of anticyclone, and behind anticyclone. The associated meteorological influences of these weather types on high-concentration events in the riverbed are explored. The monitoring data show that the hourly $\mathrm{PM}_{10}$ concentration of the four riverbed stations exceeded $125 \mathrm{~g} \mathrm{~m} \mathrm{~m}^{-3}$ for 35-465 h per year, and the maximum $\mathrm{PM}_{10}$ in the Daan (and Dajia), and Zhuoshui Rivers was more than $800 \mu \mathrm{g} \mathrm{m}^{-3}$. Weather analysis showed that the extreme $\mathrm{PM}_{10}$ concentration on the riverbed was caused by weather types: typhoon and ahead of anticyclone, in which the peak hourly concentration reached average values of more than 600 and $400 \mu \mathrm{g} \mathrm{m}^{-3}$, respectively. The high $\mathrm{PM}_{10}$ caused by the typhoon type mainly occurred in October, with an average wind speed of $6 \mathrm{~m} \mathrm{~s}^{-1}$, high temperature of $25^{\circ} \mathrm{C}$, and mostly northeasterly winds. The ahead of anticyclone type mainly occurred in December, with an average wind speed of $5 \mathrm{~m} \mathrm{~s}^{-1}$, and northeasterly and northwesterly winds. Both weather types of riverbed events were observed during the daytime, especially at noon time, when strong wind speed, high temperature, and low relative humidity is favorable for riverbed dust generation. On the other hand, the main months of the high $\mathrm{PM}_{10}$ concentrations of the ahead of front and behind anticyclone stages are February and April. The peak $\mathrm{PM}_{10}$ concentrations of these two types of riverbed events are both about $300 \mu \mathrm{g} \mathrm{m}^{-3}$, but sporadic riverbed dust in these weather stages is mixed with Asian dust or pollution transported to the rivers through weak northwesterly and northeasterly winds. The high concentrations of these two types of riverbed events can occur at any time; but for the Dadu River, the high concentrations are often observed in the morning, when land breezes from the southeast bring local pollutants to the river.
\end{abstract}

Keywords: dust aerosol; riverbed; Taiwan; $\mathrm{PM}_{10}$; front; anticyclone; weather

\section{Introduction}

Dust particles are important suspended particles in the atmosphere. In addition to affecting air quality and human health, they also have an impact on the climate [1-4]. Air pollutants can adhere to the surface of dust particles and affect human health. Besides this, dust particles can directly reflect or scatter solar radiation, or become ice condensation nuclei, indirectly affecting climate change [5-10]. Atmospheric dust particles not only come from arid deserts, but also from riverbed areas [11-13]. Similar to dust particles in the desert, dust or sand accumulations on dry riverbeds are susceptible to wind forces and can 
be raised into the air. Occasional severe riverbed events can impact on the neighboring and downwind areas, affecting visibility, health, and traffic safety [14-16].

Taiwan is an island located off the southeast coast of the Asian continent. Many rivers in Taiwan originate from high mountains, with the highest elevation of nearly $4000 \mathrm{~m}$, and are meridionally situated in the middle of the island (Figure 1). The rivers on the island are separated by the high mountains and flow either eastward or westward into the sea. Because the rivers are short and steep, the water flow is usually rapid. In addition, in the source regions, most of the geological textures of the rivers are composed of sandstone, shale, and slate. These textures are fragile and collapse easily, leading to a large amount of river sedimentation. When heavy rains occur, these sediments can be carried downstream by the rivers. As the flow rate slows down, the suspended matter in the water gradually settles and accumulates. Once the weather is dry and the wind speed is strong, the small debris on the riverbed can be raised by the wind and suspended in the air.

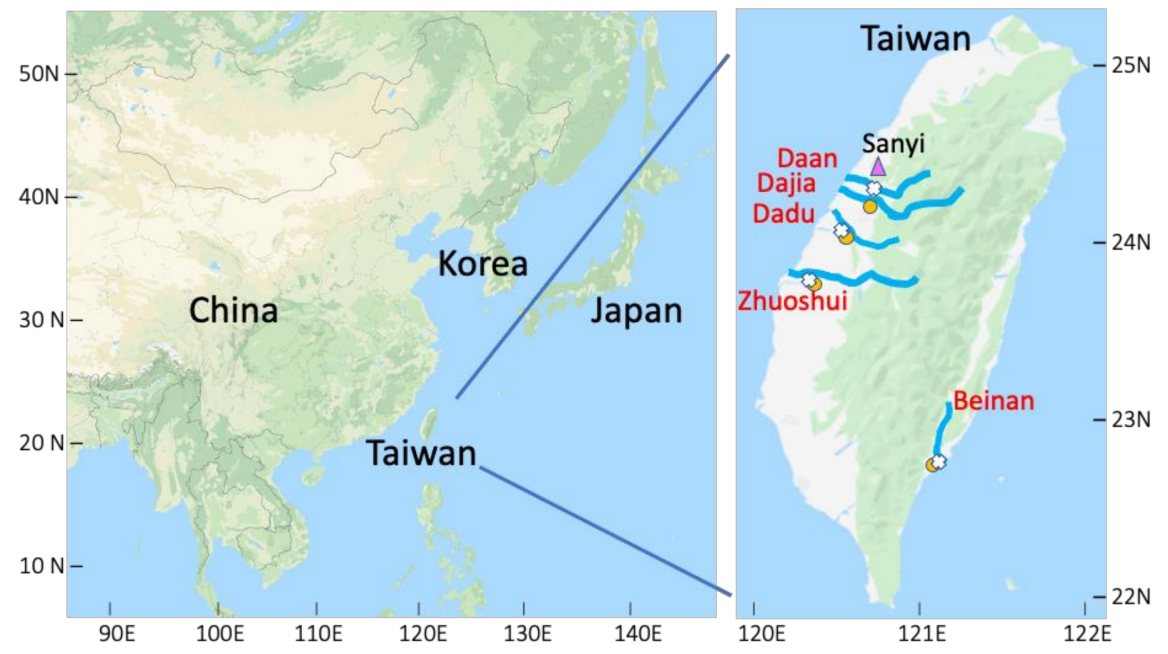

Figure 1. Locations of five major rivers in Taiwan, including the Daan, Dajia, Dadu, Zhuoshui, and Beinan. Riverbed monitoring stations are marked with a white $\mathrm{x}$, EPA monitoring stations in towns nearby the riverbed stations are marked with an orange circle, and the Sanyi background station in Central Taiwan is marked with a pink triangle (Created from Google Map).

The main rivers in Taiwan include the Daan, Dajia, Dadu, Zhuoshui, and Beinan Rivers (Figure 1). These rivers are located in the central and southeastern suburbs, and sands and gravels can be seen everywhere along the riverbeds. The annual summer monsoon period is from May to September, when typhoons and thunderstorms with heavy rainfall often occur, and the river water level is usually high. The sediments of the rivers are carried downstream by the rapid water flow. On the other hand, from October to April is the winter monsoon period. During this period, cyclonic systems with frontal events pass through Taiwan about once a week [17]. After the passage of surface fronts, the strong northeasterly winds ahead of the anticyclonic systems prevail on the island. In addition, the rainfall due to frontal passage often affects the northern areas of the island, but not the central or southern areas, where these major rivers are located. Therefore, during this period, the river waters recede and the exposed area of the dry riverbed increases. When the wind is strong enough to exceed the rising threshold of dust particles on the riverbed, they can be lifted by the wind and suspended in the air.

Besides the meteorological conditions, the riverbed dust emissions also depend on the characteristics of the rivers [14]. Among these major rivers, the Zhuoshui River has the largest watershed (approximately $3160 \mathrm{~km}^{2}$ ) and the riverbed has the largest exposed areas [18]. The maximum width of the riverbed is up to around $3 \mathrm{~km}$ at the outlet. Other rivers have smaller watersheds $\left(800-2000 \mathrm{~km}^{2}\right)$, and the riverbeds at the outlet are less than $2 \mathrm{~km}$ in width $[18,19]$. In addition, the riverbed of the lower part of the Zhuoshui River is dominated by silt, with an average particle diameter of about $1.9 \mathrm{~mm}$. Compared 
with other rivers with average sand particle diameters of $46-119 \mathrm{~mm}$, the sand particle diameter of the Zhuoshui River is relatively small $[20,21]$. Therefore, the most serious riverbed event observed in the recent decade also occurred in the Zhuoshui River, with hourly $\mathrm{PM}_{10}$ concentration reaching as high as $2532 \mu \mathrm{g} \mathrm{m}^{-3}$ on 2 November 2009 [22]. During the winter monsoon, Asian dust and pollutants, including coarse $\left(\mathrm{PM}_{2.5-10}\right)$ and fine suspended particulates $\left(\mathrm{PM}_{2.5}\right)$, can also undergo long-range transport to Taiwan through northeasterlies, resulting in the background $\mathrm{PM}_{10}$ concentrations in Northern Taiwan to an average of about $100 \mu \mathrm{g} \mathrm{m}^{-3}$ per month, or an hourly maximum of about $1000 \mu \mathrm{g} \mathrm{m}^{-3}$ over the past two decades [23-26]. Compared with Asian dust or pollutant events, the impact area of suspended particles in riverbed events is smaller but can cause extremely high concentrations in local and nearby areas.

The impacts of riverbed emissions have attracted the attentions of previous researchers [27-32]. For example, Syu et al. [31] sampled the particles of two dust events in the Zhuoshui River and found that there are two or multiple modes of particle size distributions. The higher the wind speed, the larger the size of the particles rising into the air. Lin and Yeh [14] established an empirical model to estimate the sand and dust emissions from the Zhuoshui River bed, and found that dust emission is related to wind speed, air temperature, soil silt content, and soil moisture content. Lin et al. [27] analyzed the concentration and composition of suspended particles in the lower reaches of the Zhuoshui River. They found that during the northeast monsoon, the concentration of the suspended dust particles in the riverbed would double than during other period, which would also lead to an increase in the proportion of crustal elements and a decrease in pollutant elements. Kuo et al. [29,30] and Chiang et al. [32] also found that the concentrations of metals such as $\mathrm{Ni}, \mathrm{Cr}, \mathrm{As}$, or $\mathrm{Cd}$ during riverbed dust events can reach 11 times higher than at other times, and their concentrations can seriously affect human health.

Due to the impact of the suspended riverbed dust particles, the Taiwan Environmental Protection Administration (EPA) began to establish monitoring stations near the main rivers in order to better control the emissions. Monitored data included wind speed, wind direction, temperature, relative humidity, and $\mathrm{PM}_{10}$ concentrations. In addition to wind speed, which is important for raising dust particles from the riverbed, high temperatures create more convection of the water vapor from the bare riverbed, while the relative humidity of the air is also related to water vapor, and thus they are all important factors for riverbed dust emissions [33,34]. In the present study, we analyzed the twoyear meteorological data and $\mathrm{PM}_{10}$ concentrations obtained from these major riverbed stations. In order to understand the causes of high $\mathrm{PM}_{10}$ concentration, we classified the meteorological conditions of high-concentration events into different weather types, similar to previous studies of polluted events [35,36]. Two events in the weather types are taken as examples to further illustrate the impact of weather conditions on the high concentration. The meteorological conditions in different weather types and the monthly and hourly average meteorology were summarized to explain the causes of high $\mathrm{PM}_{10}$ concentration in the riverbeds.

\section{Materials and Methods}

\subsection{Observations}

Hourly riverbed monitoring data were obtained from major riverbed stations established in Taiwan by the EPA since the end of 2009. These stations are located in central and southeastern Taiwan. Monitoring stations in Central Taiwan are set up adjacent to the Daan River (Taian Station), the Dajia River (Taian Station), the Dadu River (Xinzhuang Station), and the Zhuoshui River (Xuguang Stations), while in southeastern Taiwan a station is set up adjacent to the Beinan River (Renai Station) (Figure 1). These stations are located in the local elementary schools near the suburban rivers. The Daan River and the Dajia River are close to each other; hence they share the same monitoring station at Taian primary school.

For the four riverbed stations, the monitored data include atmospheric wind speed, wind direction, temperature, relative humidity, and $\mathrm{PM}_{10}$ concentration. The two annual 
datasets used in this study are from September 2010 to August 2011 and from September 2012 to August 2013. The riverbed data of these two years are relatively complete, and the riverbed dust-control work had not yet been performed in these two years, hence the emissions were relatively severe. In addition to the riverbed monitoring stations, this study also uses the hourly rainfall, $\mathrm{PM}_{10}$, and $\mathrm{PM}_{2.5}$ concentrations from the general EPA stations closest to the riverbed monitoring stations for comparison (Figure 1). These general EPA stations including Fengyuan, Zhanghua, Lunbei, and Taidong are located in towns near the Daan/Dajia (hereinafter, note that the two rivers share one station), Dadu, Zhuoshui, and Beinan Rivers, respectively. In addition, the $\mathrm{PM}_{10}$ concentration of the Sanyi background station (a general EPA station) located in Central Taiwan was also used as a comparison.

For riverbed stations and general EPA stations, the instruments for automatic sampling of particulate matter include the VEREWA-F701 (DURAG, Hamburg, Germany) and the BAM-1020 (Met One, Grants Pass, OR, USA) monitors. They were operated at a gas

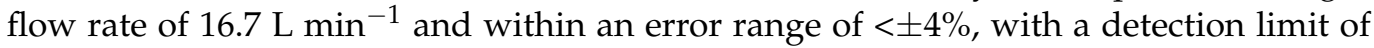
$2 \mu \mathrm{g} \mathrm{m}^{-3}$, respectively. For automatic measuring of temperature/relative humidity, wind speed, wind direction, and rain, the instruments used were Met One 083D, Met One 014A, Met One $024 \mathrm{~A}$, Met One 370 , and the precision is within $0.5^{\circ} \mathrm{C} / \pm 5 \%, \pm 1.5 \%, \pm 5^{\circ}$, and $\pm 0.2 \mathrm{~mm}$, respectively.

\subsection{Classification of Weather Types}

In order to understand the impact of meteorological conditions on the high concentration of $\mathrm{PM}_{10}$ in the riverbeds, this study selected high-concentration dust events with a daily $\mathrm{PM}_{10}$ greater than the air quality standard of $125 \mu \mathrm{g} \mathrm{m} \mathrm{m}^{-3}$ for further analysis. Since most of these high-concentration events occurred during the winter monsoon, when Taiwan was mainly affected by the front and anticyclonic circulation, these events were further classified according to the weather conditions, that is, Taiwan's position ahead of the front, ahead of the anticyclonic system, and behind the anticyclonic system, similar to previous studies of air pollution $[35,36]$. In addition to the three weather stages that occur during the winter monsoon, September and October are the transitional months between the winter monsoon and the summer monsoon, during which some serious riverbed events have also occurred due to the impact of typhoons. Therefore, we divide the meteorological conditions of these high riverbed events into typhoon and non-typhoon types. For events without typhoons, they are further classified according to the three stages of weather conditions mentioned above.

\section{Data Analysis}

\subsection{Hourly Observations}

Figure 2 shows the observed hourly relative humidity, temperature, $\mathrm{PM}_{10}$ concentration, and noon time wind speed and direction observed by four riverbed monitoring stations, as well as rainfall at general EPA stations near each river (Figure 2a-d). Observations from the Sanyi background station in central Taiwan are also plotted for comparison (Figure 2e). Two annual datasets, starting from September 2010 and September 2012, for all stations are plotted. In these figures, we can roughly divide the data into two periods, namely the winter monsoon and the summer monsoon. From October to April is usually the period of the winter monsoon. It can be seen in Figure 2 that the northeasterly or northerly winds prevailed at most riverbed stations during this period, and the temperature, humidity, and rainfall were relatively low, indicating the dry and windy seasons of the year. This is the period when more dust particles are generated from the riverbeds. On the other hand, during the summer monsoon period, the wind is usually weaker and wind direction is more diversified, and the relative humidity and rainfall are higher, resulting in fewer riverbed events. Among all the rivers, the Beinan is located in the southernmost position and is also on the edge of the prevailing northeasterly wind in winter (Figure 1). Therefore, even in the northeasterly seasons, the local land sea breezes often dominate. The wind direction at noon time (12:00) in Figure $2 \mathrm{~d}$ shows that the sea breezes from the 
south are often observed in the riverbed area during the winter monsoon, and the wind direction is different from the northerlies or northeasterlies prevailing at the stations in Central Taiwan. These details can be seen later in the case study.

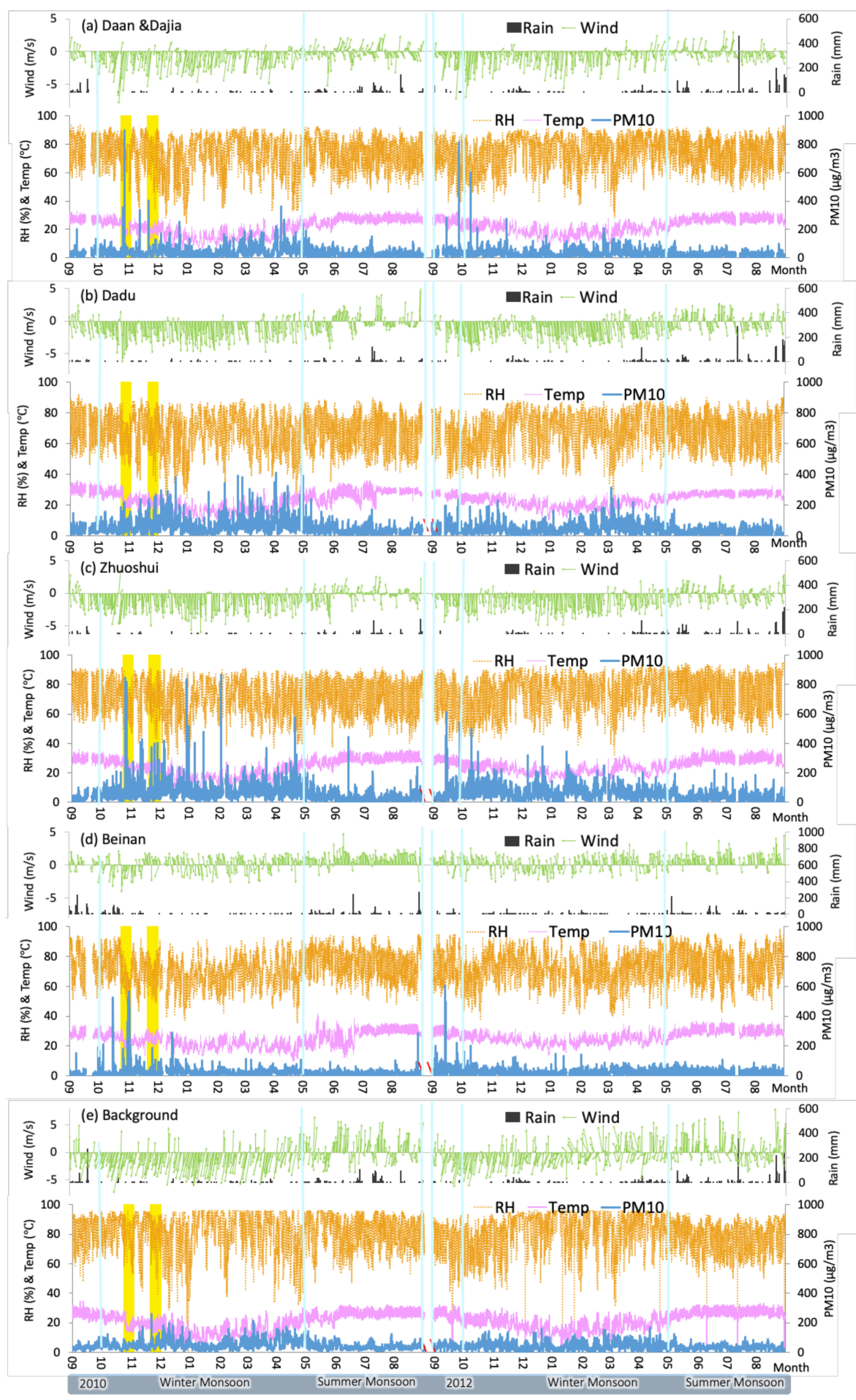

Figure 2. Wind speed and direction, relative humidity (orange line), temperature (pink line), and $\mathrm{PM}_{10}$ concentration observed at the (a) Daan and Dajia, (b) Dadu, (c) Zhuoshui, and (d) Beinan riverbed monitoring stations, and rainfall amounts observed at the closest general EPA stations adjacent to the rivers from 1 September 2010 to 31 August 2011, and 1 September 2012 to 31 August 2013. Observations from (e) Sanyi background station are plotted for comparison. Two selected events for discussion are marked with yellow bars. 
Comparing the monitoring results of the four rivers, the riverbed event in the Zhuoshui River in Central Taiwan was more serious than events in other rivers (Figure 2). The $\mathrm{PM}_{10}$ concentration in the Zhuoshui River exceeded $400 \mu \mathrm{g} \mathrm{m}{ }^{-3}$ in $16 \mathrm{~h}$ per year, of which it exceeded $800 \mu \mathrm{g} \mathrm{m}^{-3}$ in $2.5 \mathrm{~h}$. In Daan/Dajia, the $\mathrm{PM}_{10}$ concentration exceeded $400 \mu \mathrm{g} \mathrm{m}^{-3}$ in $5 \mathrm{~h}$ per year, of which one hour exceeded $800 \mu \mathrm{g} \mathrm{m}^{-3}$. For the Beinan River in southeastern Taiwan, $\mathrm{PM}_{10}$ was observed to exceed $400 \mu \mathrm{g} \mathrm{m}^{-3}$ in $5 \mathrm{~h}$ per year. Similar to the Daan/Dajia and Zhuoshui Rivers, the Dadu River is also located in Central Taiwan, but the maximum hourly concentrations of $\mathrm{PM}_{10}$ exceeds $400 \mu \mathrm{g} \mathrm{m}^{-3}$ only once per year. In addition, aerosol transported from the Asian continent or local pollution to the riverbeds is limited. At the Sanyi background station in Central Taiwan (Figure 2e), the highest hourly $\mathrm{PM}_{10}$ concentrations in the two years were about $250 \mu \mathrm{g} \mathrm{m}^{-3}$, representing the hourly maximum $\mathrm{PM}_{10}$ value due to long-range transport to the island from abroad. Moreover, the hourly $\mathrm{PM}_{10}$ of the largest city in Central Taiwan (Taichung) is also less than $250 \mu \mathrm{g} \mathrm{m}^{-3}$ in the two years. Thus, the $\mathrm{PM}_{10}$ concentration due to dust generation from these major rivers is extremely high.

\subsection{Average of Hourly Observations}

Figure 3 summarizes the $\mathrm{PM}_{10}$ and meteorological values from Figure 2. Figure $3 \mathrm{a}$ presents the annual and monthly averaged $\mathrm{PM}_{10}$ concentrations of the major rivers. The results show that although the hourly $\mathrm{PM}_{10}$ concentration in the riverbed is as high as $800 \mu \mathrm{g} \mathrm{m}^{-3}$, the annual average $\mathrm{PM}_{10}$ concentration in all major rivers is not high. The value range is only $21-57 \mathrm{\mu g} \mathrm{m}^{-3}$, indicating that the rivers are located in rural areas. The largest annual averaged $\mathrm{PM}_{10}$ is the Zhuoshui River in Central Taiwan, with a value of $57 \mu \mathrm{g} \mathrm{m}^{-3}$, and the lowest is the Beinan River in southeastern Taiwan, with a value of $21 \mu \mathrm{g} \mathrm{m}^{-3}$. In addition, the maximum monthly average of $\mathrm{PM}_{10}$ was observed in the Zhuoshui River, with a concentration of $89 \mu \mathrm{g} \mathrm{m}^{-3}$, which appeared in December. This maximum monthly average of the Zhuoshui River is more than three times the minimum value observed in July $\left(25 \mu \mathrm{g} \mathrm{m}^{-3}\right)$. Similarly, the monthly average $\mathrm{PM}_{10}$ concentrations during the winter monsoon period (October to April) are all higher than those in the summer monsoon periods (May to September) for other stations, but the ratio of maximum to minimum monthly averages are all around 3. Although the higher $\mathrm{PM}_{10}$ in the riverbeds during the winter monsoon may come from the long-range transport of Asian dust and pollutants, previous studies reported that the monthly or annual average increase in Northern Taiwan is up to about $20 \mu \mathrm{g} \mathrm{m}^{-3}[23,26]$, indicating the impacts of riverbed dust on $\mathrm{PM}_{10}$ concentration.

Figure $3 b$ counts the total number of days in which the daily averaged $\mathrm{PM}_{10}$ of all riverbeds exceeded the air quality standard of $125 \mu \mathrm{g} \mathrm{m}^{-3}$ in each month. The results showed that the daily average $\mathrm{PM}_{10}$ exceedance time of all rivers was within 3 days per month, of which the maximum 3 days was observed in the Dadu River in April. In addition, for the entire year, the maximum number of 10 days was observed in the Zhuoshui River. This is because in the Zhuoshui River, the daily $\mathrm{PM}_{10}$ exceeds the standard for nearly half a day to 2.5 days per month in the winter. On the other hand, the Daan/Dajia Rivers exceed the standard value for half a day in September and October, while the Beinan River only exceeds the standard for half a day in October. The low daily average $\mathrm{PM}_{10}$ exceedance time of all rivers in Figure $3 b$ indicates that the high riverbed concentrations occur sporadically within a few hours, and the background concentration of the rivers is relatively low during the rest of the day, and thus the daily average $\mathrm{PM}_{10}$ is not high.

Figure $3 \mathrm{c}$ shows the average concentration of $\mathrm{PM}_{10}$ for $24 \mathrm{~h}$. Similar to the monthly average $\mathrm{PM}_{10}$ in Figure $3 \mathrm{a}$, the hourly average $\mathrm{PM}_{10}$ of the riverbed is not high, with the highest values being $65 \mathrm{\mu g} \mathrm{m}^{-3}$, and appears after noon time (14:00) in the Zhuoshui River. The Daan/Dajia, and Beinan Rivers also have similar high concentrations during the day and low concentrations at night, while the hourly variation of the Dadu River is different from that of other rivers. The high concentration appeared in the morning, and the maximum value was as high as $60 \mu \mathrm{g} \mathrm{m}^{-3}$ at 7 a.m. In addition to the morning hours, 
the other hourly average values of the Dadu River are almost all slightly lower than in the Zhuoshui River, which is the river with the second highest concentration.

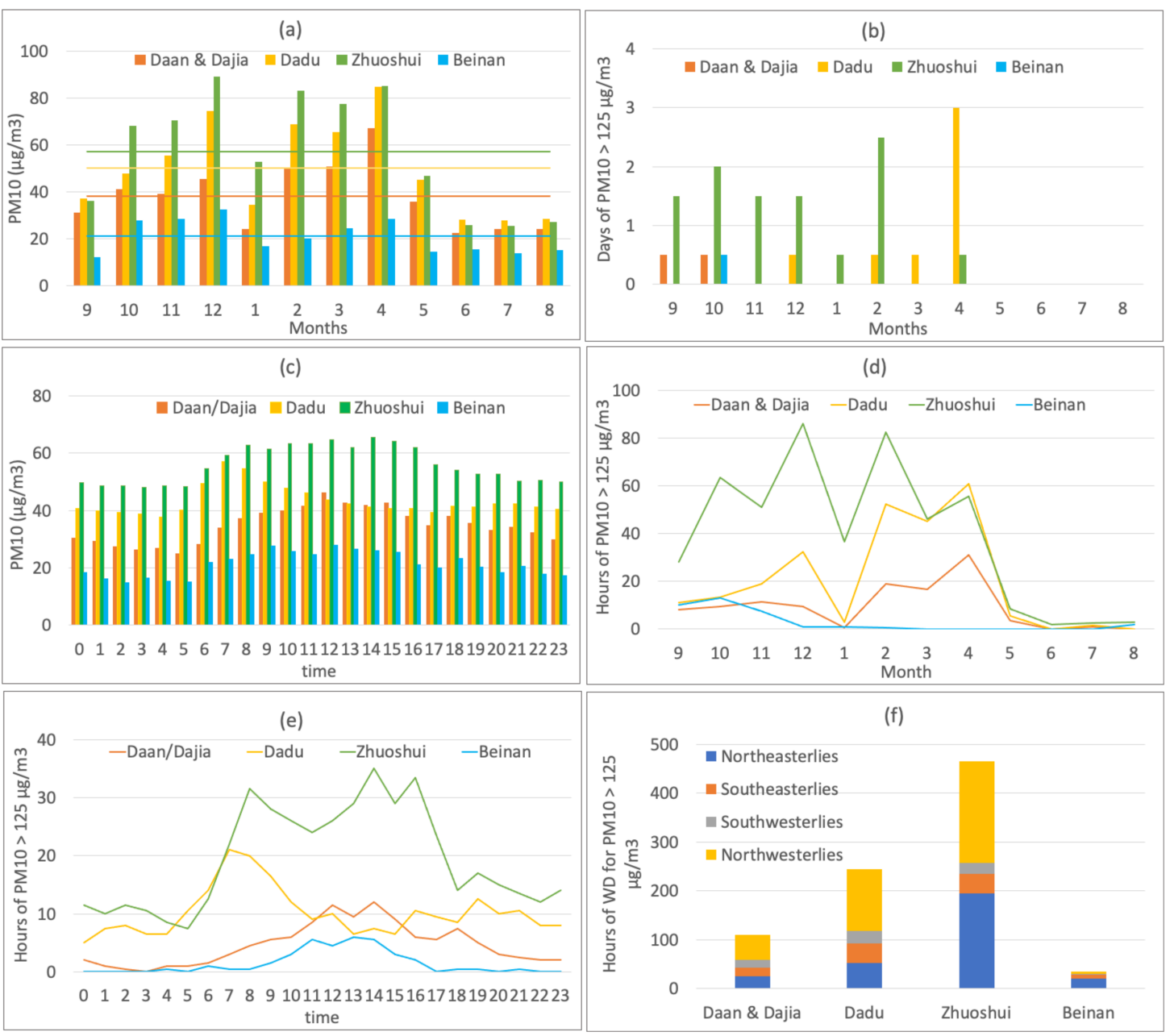

Figure 3. Summary from Figure 2, (a) monthly average $\mathrm{PM}_{10}$ concentration, (b) daily counts of $\mathrm{PM}_{10}$ greater than $125 \mu \mathrm{g} \mathrm{m}^{-3}$ in each month, (c) annual average $\mathrm{PM}_{10}$ concentration in each hour, (d) hourly counts of $\mathrm{PM}_{10}$ greater than $125 \mu \mathrm{g} \mathrm{m}{ }^{-3}$ in each month, (e) hourly counts of $\mathrm{PM}_{10}$ greater than $125 \mu \mathrm{g} \mathrm{m}^{-3}$ in each hour, and (f) hourly counts of wind directions per year for hourly $\mathrm{PM}_{10}$ greater than $125 \mu \mathrm{g} \mathrm{m}^{-3}$.

In order to inspect the occasional high concentrations of $\mathrm{PM}_{10}$ in the riverbed, this study counts the hours of high $\mathrm{PM}_{10}$ concentration. Since the EPA does not have an hourly air quality standard for $\mathrm{PM}_{10}$, we have used the $125 \mu \mathrm{g} \mathrm{m}^{-3}$ from the $\mathrm{PM}_{10}$ daily air quality standard as the criteria for selecting hourly high-concentration cases. Figure $3 \mathrm{~d}$ shows the total number of hours exceeding $125 \mu \mathrm{g} \mathrm{m}^{-3}$ per month for all the rivers in an annual average. The results further highlight that the high concentration of $\mathrm{PM}_{10}$ varies by month and river. During the winter monsoon from October to April of the following year, the maximum number of exceedance hours per month is more than $80 \mathrm{~h}$, while during the summer monsoon period, the value is almost zero in all rivers. Comparing different months, Figure $3 \mathrm{~d}$ shows that the distribution of $\mathrm{PM}_{10}$ exceedance time is similar to the monthly average distribution in Figure 3a, showing a bimodal type, among which December, February, and April are the months with more exceedance hours for the Daan/Dajia, Dadu, and Zhuoshui Rivers in Central Taiwan. The high number of hours exceeding the criteria in these several months also resulted in high averaged concentrations in these rivers (Figure 3a). In Figure 3d, January is the month when the $\mathrm{PM}_{10}$ exceedance time is the lowest in the winter monsoon, which also results in the lowest monthly average concentration in 
the season. In addition to these few months, the number of hourly $\mathrm{PM}_{10}$ values exceeding the criteria in the Zhuoshui River was also high in October, and in the Beinan River in southeastern Taiwan was also high in September and October.

When comparing different rivers, Figure $3 \mathrm{~d}$ shows that the maximum time exceeding the criteria per month was $86 \mathrm{~h}$, which occurred in the Zhuoshui River in December, and the total exceedance is $465 \mathrm{~h}$ for the same river in a year. Converting 465 or $86 \mathrm{~h}$ into days, there are almost 19 days a year, or 4 days a month, of exceedance time. Interestingly, the number of days when daily $\mathrm{PM}_{10}$ exceeded the standard in the Zhuoshui River was only 10 days per year, and in December it was only 1.5 days (Figure $3 \mathrm{~b}$ ). These results indicate again that high concentrations of $\mathrm{PM}_{10}$ are mostly sporadic for a few hours of the day, rather than continuously occurring, so that the daily average value exceeding the standard is rare, which is different from the high concentration of the Asian dust event observed for several consecutive days [36]. However, if the 465 or $86 \mathrm{~h}$ of over-criteria time are evenly distributed to 365 in a year, or 30 days in a month, the riverbed has from $1 \mathrm{~h}$ to nearly $3 \mathrm{~h}$ a day when $\mathrm{PM}_{10}$ concentration has reached a value of $125 \mu \mathrm{g} \mathrm{m}^{-3}$. For the Daan/Dajia, and Dadu Rivers, the total number of hours exceeding $125 \mu \mathrm{g} \mathrm{m}{ }^{-3}$ per month corresponds to about $2 \mathrm{~h}$ and $1 \mathrm{~h}$ per day in the severe months, respectively. Therefore, although the daily $\mathrm{PM}_{10}$ exceedance time is low, high dust concentrations are often observed over these rivers, especially in severe months.

Figure $3 e$ counts the total number of hours when $\mathrm{PM}_{10}$ exceeds $125 \mu \mathrm{g} \mathrm{m}^{-3}$ in each $24 \mathrm{~h}$. It can be seen from the figure that the $\mathrm{PM}_{10}$ exceedance hour is unevenly distributed within $24 \mathrm{~h}$. Most riverbeds show high exceedance hours during the daytime. Among all the rivers, the maximum exceedance occurs in the Zhuoshui River, and the over-criteria time from 8:00 to 16:00 during the day is about 25 to $35 \mathrm{~h}$ per year, indicating that the riverbed emissions may be higher during these periods. The Daan/Dajia, and Beinan Rivers have similar high $\mathrm{PM}_{10}$ concentrations at noon time, but the frequency is less. Different from other rivers, the Dadu River's maximum exceedance occurred in the morning, and the value $(20 \mathrm{~h})$ is only slightly lower than that of the Zhuoshui River at the same time, similar to the result in Figure 3c. In addition to the daytime exceedance, Figure 3e shows that most rivers in Central Taiwan have also observed high $\mathrm{PM}_{10}$ events at night, implying that the $\mathrm{PM}_{10}$ in these rivers may have other sources.

In addition to monthly and hourly variations in high riverbed concentrations, the wind directions in all rivers that cause hourly $\mathrm{PM}_{10}$ to exceed $125 \mu \mathrm{g} \mathrm{m}^{-3}$ are also summarized. In order to simplify the wind problem, all wind directions are only divided into four directions, 0 to 90 degrees as northeasterlies (NE), 90 to 180 degrees as southeasterlies (SE), 180 to 270 degrees as southwesterlies (SW), and 270 to 360 degrees as northwesterlies (NW). Figure $3 \mathrm{f}$ shows the total number of hours per year for different wind directions leading to high riverbed concentrations. In Figure $3 \mathrm{f}$, the Zhuoshui River has the longest time exceeding the standard per year $(465 \mathrm{~h})$, and the Beinan River has the shortest time exceeding the standard per year $(35 \mathrm{~h})$. Regardless of the wide range of exceedance time, Figure $3 \mathrm{f}$ shows that the main wind directions are northeasterly and northwesterly winds, which account for at least $70 \%$ of all riverbed high-concentration events, observed mainly in the northeasterly monsoon seasons. In addition, southwesterly and southeasterly winds are also important, accounting for at least about $15 \%$ of the high-concentration events for all the rivers.

Furthermore, we also checked other meteorological conditions that caused the hourly $\mathrm{PM}_{10}$ value to exceed $125 \mu \mathrm{g} \mathrm{m}^{-3}$, including wind speed, temperature, and humidity. The results showed that all rivers have a wide range of wind speed during high concentrations of hourly $\mathrm{PM}_{10}$. The maximum wind speed was as high as $11 \mathrm{~m} \mathrm{~s}^{-1}$, but the minimum wind speed was only $0.2 \mathrm{~m} \mathrm{~s}^{-1}$. The temperature range was likely to be from 11 to $34^{\circ} \mathrm{C}$, and the humidity range was from $33 \%$ to $94 \%$ at the high hourly concentration of $\mathrm{PM}_{10}$. The wide ranges of the meteorological conditions at high $\mathrm{PM}_{10}$ concentration may be caused by the meteorological conditions of various weather types and will be explored in the following sections. 


\section{Weather Analysis}

To explain the monthly and hourly $\mathrm{PM}_{10}$ variations shown in Figure 3, riverbed dust events with daily $\mathrm{PM}_{10}$ greater than $125 \mu \mathrm{g} \mathrm{m}^{-3}$, as discussed in Figure $3 \mathrm{~b}$, are selected for weather analysis. Table 1 lists the selected days during the two-year period. For each day in Table 1, the weather type is classified according to the weather map, as described in Section 2.2. The first events from both the typhoon and non-typhoon types are selected for illustration in the following sections.

Table 1. Riverbed events (day/month/year) with daily averaged $\mathrm{PM}_{10}$ greater than $125 \mu \mathrm{g} \mathrm{m}^{-3}$ for each of the major rivers are classified into different types.

\begin{tabular}{|c|c|c|c|c|}
\hline \multirow[b]{2}{*}{ Rivers/Types } & \multirow[b]{2}{*}{ Typhoon } & \multicolumn{3}{|c|}{ Non-Typhoon } \\
\hline & & Ahead of Front & $\begin{array}{c}\text { Ahead of } \\
\text { Anticyclone }\end{array}$ & $\begin{array}{c}\text { Behind } \\
\text { Anticyclone }\end{array}$ \\
\hline Daan \& Dajia & $\begin{array}{l}27 / 10 / 2010 \\
28 / 09 / 2012\end{array}$ & & & \\
\hline Dadu & & $\begin{array}{c}13 / 12 / 2010 \\
10-11 / 04 / 2011\end{array}$ & & $\begin{array}{c}01-02 / 04 / 2011 \\
14 / 04 / 2011 \\
29 / 04 / 2011 \\
25 / 02 / 2013 \\
06 / 03 / 2013\end{array}$ \\
\hline Zhuoshui & $\begin{array}{c}26-27 / 10 / 2010 \\
14 / 09 / 2012 \\
28-29 / 09 / 2012 \\
10 / 10 / 2012 \\
17 / 10 / 2012\end{array}$ & $\begin{array}{l}22 / 11 / 2010 \\
11 / 04 / 2011 \\
26 / 02 / 2013\end{array}$ & $\begin{array}{l}28 / 11 / 2010 \\
31 / 12 / 2010 \\
15 / 01 / 2011 \\
09 / 02 / 2011 \\
23 / 12 / 2012\end{array}$ & $\begin{array}{l}12 / 11 / 2010 \\
23 / 12 / 2010 \\
07 / 02 / 2011 \\
26 / 02 / 2011 \\
25 / 02 / 2013\end{array}$ \\
\hline Beinan & & & $31 / 10 / 2010$ & \\
\hline
\end{tabular}

\subsection{Weather Maps of Two Types}

Figure 4 shows the weather maps of the first events of the typhoon and non-typhoon types, in which the latter is further classified into ahead of front, ahead of anticyclone, and behind anticyclone. In Figure 4a, the first typhoon type was observed on 27 October 2010 (also see Table 1). In this event, Typhoon Chaba approached Taiwan from near the equator, and later turned northeast to the Japanese coast without passing through Taiwan. On the other hand, a strong anticyclonic circulation occupied China on the same day, and there was an intensive pressure gradient in the coastal areas of China. Due to this strong pressure gradient, strong northeasterly winds prevailed in Taiwan. The approach of the cyclonic circulation of the typhoon accelerated the strong northeasterlies, resulting in the rising of the riverbed sands and dust particles, and has led to the daily $\mathrm{PM}_{10}$ exceedance over the Daan/Dajia and Zhuoshui Rivers (Table 1). Although typhoons are warm and humid cyclones, and often produce rainfall, Typhoon Chaba was far away from Taiwan, so less than $1 \mathrm{~mm}$ of precipitation was observed in southeastern Taiwan, and no precipitation was observed in the riverbed area of Central Taiwan.

For the non-typhoon type, Figure $4 \mathrm{~b}-\mathrm{d}$ show the weather map of the first consecutive event from 20 November to 30 November 2010. The event includes weather conditions such as Taiwan's location ahead of the surface front (Figure $4 \mathrm{~b}$ ), ahead of the anticyclonic system (Figure 4c), and behind the anticyclonic system (Figure 4d). This event caused the daily averaged $\mathrm{PM}_{10}$ values of the Zhuoshui River to exceed the standard for two days $(22 / 11 / 2010$ and $28 / 11 / 2010$ in Table 1$)$. Figure $4 \mathrm{~b}$ shows the ahead of the front type of weather on 21 November 2010. In this type, a surface front was located on the southeast coast of China, which was about to pass through Taiwan.

After the passage of the surface front, Taiwan was under northeasterly winds ahead of the anticyclonic system. Figure 4c shows the weather map of this type on 25 November 2010. The northeasterly wind lasted for several days until the anticyclonic center moved off the coastal areas of China. Figure $4 \mathrm{~d}$ shows that after the anticyclonic center passed 
through areas to the north of Taiwan on 28 November 2010, most areas of Taiwan were dominated by weak easterly winds.
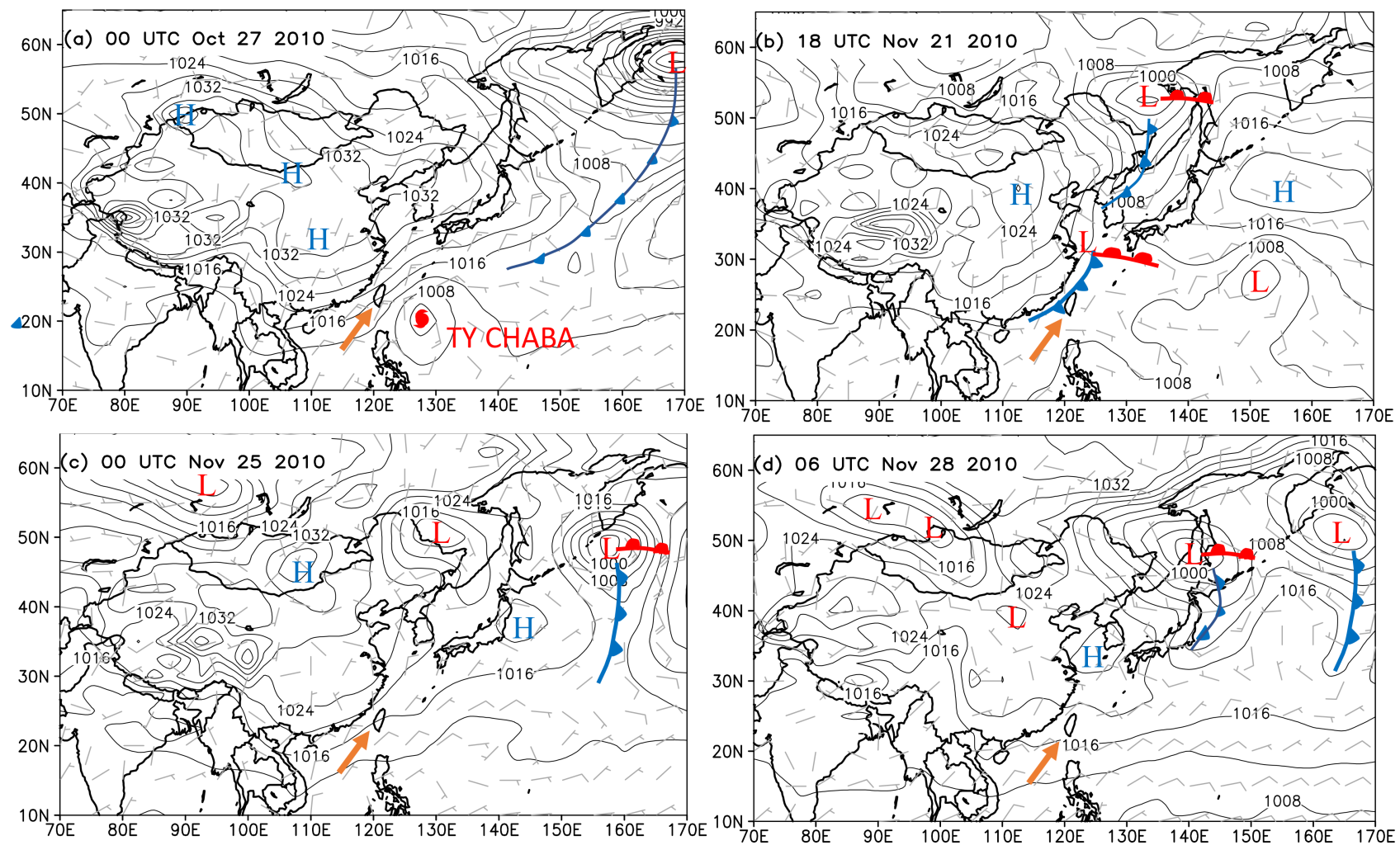

Figure 4. Surface weather maps of (a) typhoon (TY Chaba) type at 00:00 UTC on 27 October 2010; (b) ahead of front in non-typhoon type at 18:00 UTC on 21 November 2010; (c) ahead of anticyclone in non-typhoon type at 00:00 UTC on 25 November 2010; and (d) behind anticyclone in non-typhoon type at 06:00 UTC on 28 November 2010. The full barb and half barb represent 10 and $5 \mathrm{~m} \mathrm{~s}^{-1}$, respectively. Isobars (line) are analyzed at $4 \mathrm{hPa}$ interval. Taiwan is marked with an arrow. Note that the universal time in the weather map plus $8 \mathrm{~h}$ is the local time (created by data from the National Centers for Environmental Prediction, US).

\subsection{Hourly Data of Two Types}

Figures 5 and 6 plot $\mathrm{PM}_{10}$ concentration and meteorological data of all riverbeds for the typhoon and non-typhoon types discussed in Figure 4. Figure 5 shows the typhoon type data from 24 October to 2 November 2010. In this type, Typhoon Chaba approached Taiwan from 26 to 27 October. Before the arrival of the typhoon on 24 October, land breezes (easterlies on the western coast) were observed in most riverbeds from the evening to early morning, and then sea breezes (westerlies on the western coast) during the day (Figure 5). The land-sea breeze is in the reverse wind direction in the Beinan River over the southeastern coast of Taiwan. 


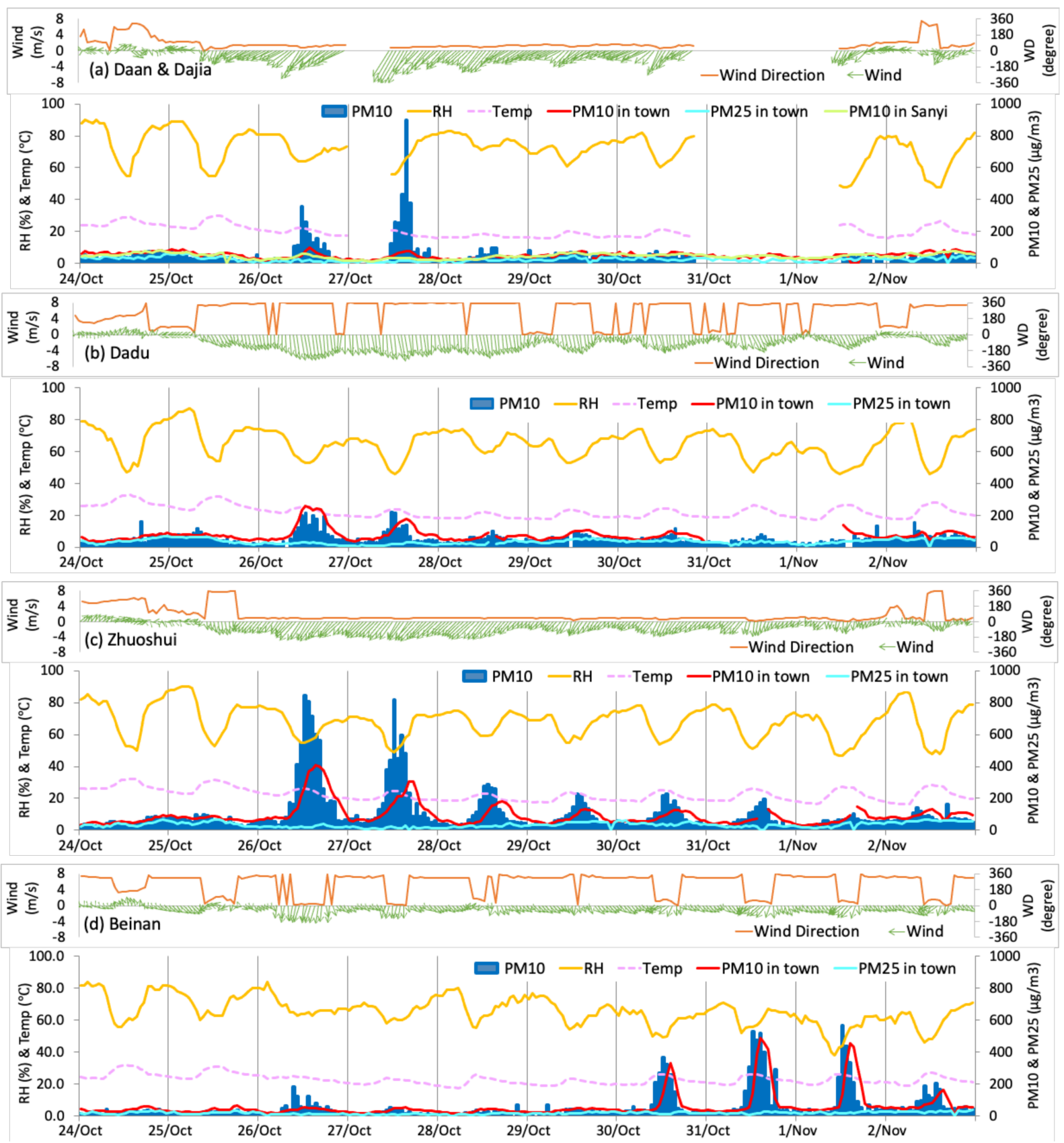

Figure 5. The typhoon type meteorological conditions and aerosol concentration, including wind speeds and directions (wind and WD), relative humidity $(\mathrm{RH})$, temperature (Temp), and $\mathrm{PM}_{10}$ concentration observed at (a) Daan and Dajia, (b) Dadu, (c) Zhuoshui, and (d) Beinan riverbed monitoring stations from 24 October to 2 November 2010. $\mathrm{PM}_{10}$ and $\mathrm{PM}_{2.5}$ observed in the town nearby each riverbed stations and $\mathrm{PM}_{10}$ in the Sanyi background station are also plotted. 


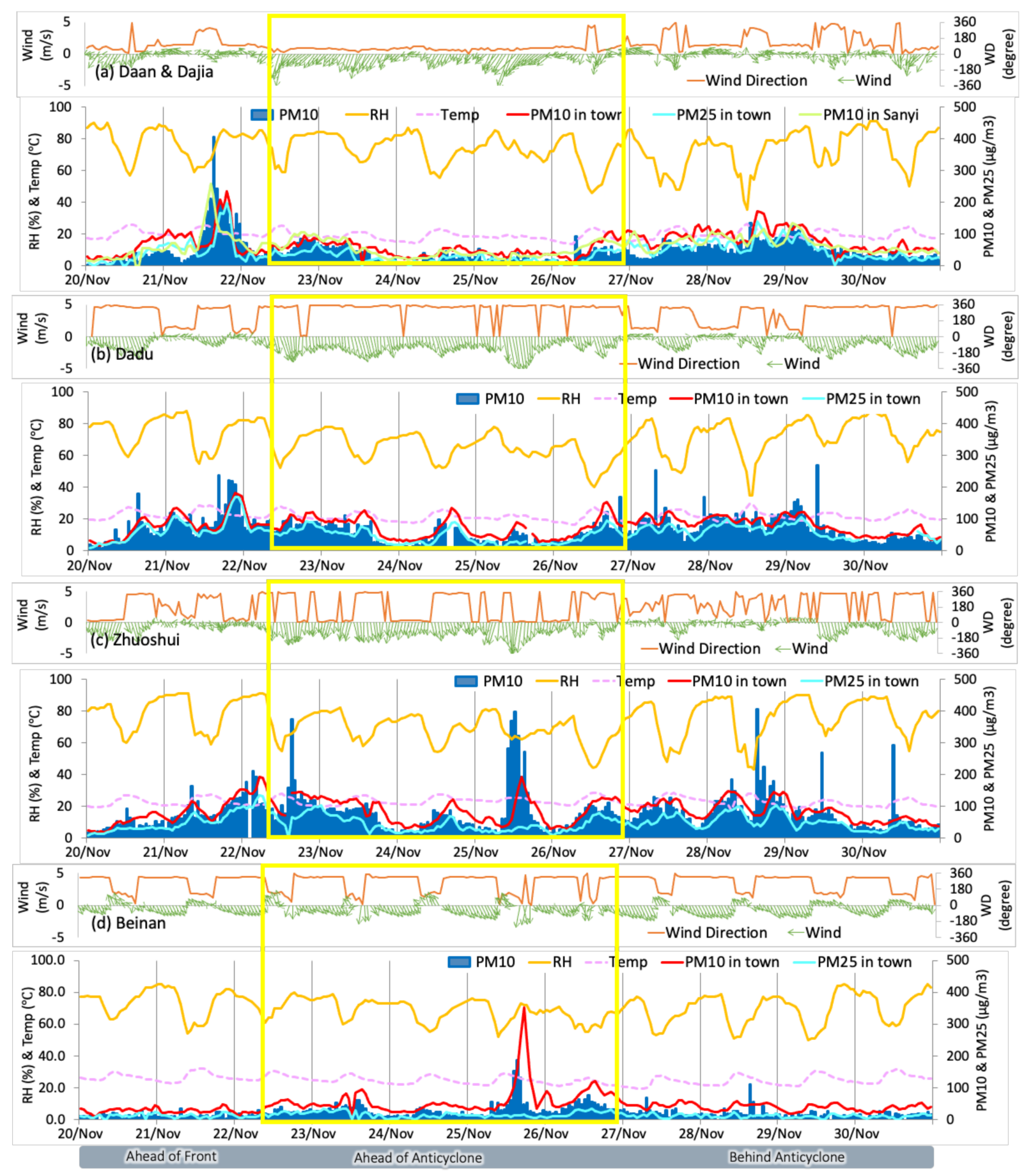

Figure 6. Same as in Figure 5, except for the non-typhoon type that occurred from 20 November to 30 November 2010. The ahead of anticyclone stage is marked with a yellow rectangle.

Followed by the local land-sea breeze on early 25 October, the northeasterlies ahead of the surface anticyclonic system started to affect the coastal areas of East Asia. From 26 to 27 October, the northeasterlies reached their maximum surface wind speed due to the approach of the typhoon. The maximum surface wind speed observed at the Daan/Dajia Rivers was close to $10 \mathrm{~m} \mathrm{~s}^{-1}$, while at other sites in Central Taiwan it remained at $7 \mathrm{~m} \mathrm{~s}^{-1}$, and at the Beinan River in southeastern Taiwan it decreased to $5 \mathrm{~m} \mathrm{~s}^{-1}$. Under the extremely high wind speeds, all riverbed stations observed an increase in $\mathrm{PM}_{10}$ concentration (Figure 5). On 26 and 27 October, the hourly maximum of $\mathrm{PM}_{10}$ was around 350 and $900 \mu \mathrm{g} \mathrm{m}^{-3}$ at the Daan/Dajia Rivers, respectively, while at the Zhuoshui River, it exceeded 
$800 \mu \mathrm{g} \mathrm{m}^{-3}$ on both days (also see Figure 2 ). The $\mathrm{PM}_{10}$ concentration of the Dadu and Beinan Rivers is lower, but the maximum hourly value is also about $200 \mu \mathrm{g} \mathrm{m}^{-3}$. In addition, the hourly $\mathrm{PM}_{10}$ concentrations at the Sanyi background station in Central Taiwan during the entire event was less than $70 \mu \mathrm{g} \mathrm{m}^{-3}$ (Figure 5a), indicating the impacts of long-range transport of aerosol from the Asian continent were small. Also, note that although the prevailing wind was strong throughout the day, the riverbed dust concentration was only enhanced during the day and reached its peak at noon time, when the temperature was warmer and relative humidity of all the rivers decreased to less than $60 \%$, indicating these conditions are conducive to riverbed dust generation.

Among all the rivers, the Zhuoshui River has more obvious riverbed dust enhancement than other rivers (Figure 5c). Except for the extremely high $\mathrm{PM}_{10}$ concentration on 26 and 27 October, $\mathrm{PM}_{10}$ concentration exceeding $200 \mu \mathrm{g} \mathrm{m}^{-3}$ continued for several days in the river until 31 October. The maximum hourly wind speed observed on the Zhuoshui River during the event $\left(7 \mathrm{~m} \mathrm{~s}^{-1}\right)$ was lower than the wind speed observed on the Daan/Dajia Rivers $\left(10 \mathrm{~m} \mathrm{~s}^{-1}\right)$, and was roughly the same as the wind speed observed on the Dadu River. In addition, the temperature $\left(23-24{ }^{\circ} \mathrm{C}\right)$ and relative humidity $(49-58 \%)$ at the peak $\mathrm{PM}_{10}$ concentration from 27 to 31 October are similar to those of the Dadu River $\left(21-25{ }^{\circ} \mathrm{C}\right.$, $46-60 \%)$. However, the maximum concentration of $\mathrm{PM}_{10}$ in the Zhuoshui River was more than $800 \mu \mathrm{g} \mathrm{m}^{-3}$ and $\mathrm{PM}_{10}$ enhancement lasted for a few days, while the concentration in the Dadu River reached $200 \mu \mathrm{g} \mathrm{m}^{-3}$ only in the first two days. This suggests that in addition to meteorological conditions, different riverbed characteristics are critical to riverbed dust generation.

After the typhoon, the $\mathrm{PM}_{10}$ concentrations of most rivers decreased, but the opposite occurred in the Beinan River (Figure 5d). From 30 October to 2 November 2010, high $\mathrm{PM}_{10}$ concentrations were observed in the Beinan River at noon time, and the maximum concentration exceeded $500 \mu \mathrm{g} \mathrm{m}^{-3}$. The wind speed on these days only reached around $4 \mathrm{~m} \mathrm{~s}^{-1}$, and was less than the peak wind speed (close to $5 \mathrm{~m} \mathrm{~s}^{-1}$ ) during the typhoon period. However, the Beinan River is located on the southeastern coast of Taiwan, directly facing the warm and humid air brought by the typhoon's peripheral circulation, which suppressed the uplifting of dust particles from riverbeds. After the typhoon left, the northeast monsoon followed and the relative humidity decreased to a minimum below $40 \%$. Thus, the riverbed dust particles were uplifted under windy and dry conditions, showing the importance of humidity as a factor. In addition, Figure $5 \mathrm{~d}$ shows that the $\mathrm{PM}_{10}$ concentration in the town near the riverbed increased during this period. Similarly, the $\mathrm{PM}_{10}$ concentrations in towns near other riverbeds also increased during the typhoon period (Figure 5). Since the concentration of $\mathrm{PM}_{2.5}$ in towns and $\mathrm{PM}_{10}$ in the background Sanyi station were both low during the event, indicating low local pollution or foreign dust concentrations. The high $\mathrm{PM}_{10}$ concentration in towns suggests that the coarse particles from riverbeds have affected those nearby towns.

The second selected weather type is without typhoon, which occurred from 20 November to 30 November 2010, and Figure 6 shows the observed data of this type. In this type, three meteorological stages were observed, including ahead of a surface front, ahead of an anticyclonic system, and behind an anticyclonic system. At the beginning of this type on 21 November, a surface front was approaching Taiwan (Figure 4b). At this time, the wind speed was low and the atmosphere was stable. In addition, due to the approach of the cyclonic circulation of the low-pressure system, southwesterly winds were easily seen in some areas of Western Taiwan [36], causing the pollutants to accumulate over the marginal sea and northwestern Taiwan (Figure S1). In the riverbed area of Central Taiwan, the sea breeze from the northwest prevailed at noon time, bringing pollutants into the riverbed areas (Figure $6 \mathrm{a}-\mathrm{c}$ ). Under the northwesterly wind, high $\mathrm{PM}_{10}$ concentration was observed over the Daan/Dajia Rivers, with the maximum value exceeding $400 \mu \mathrm{g} \mathrm{m}^{-3}$ (Figure 6a). Since concentrations of $\mathrm{PM}_{10}$ in the Sanyi background station and the $\mathrm{PM}_{2.5}$ in riverside towns were both about $200 \mu \mathrm{g} \mathrm{m}^{-3}$ at the same time, it suggests that other than the riverbed dust raised by the wind speed, the pollutants carried by the westerly wind affected the 
riverbeds of the Daan/Dajia Rivers and surrounding areas. The $\mathrm{PM}_{10}$ concentration of other rivers in Central Taiwan also increased, but the time was slightly delayed from north to south (Figure $6 b, c$ ).

After the frontal passage on early 22 November, the northeast monsoon prevailed ahead of the anticyclonic system. On 25 November, another anticyclonic system with a strong pressure gradient affected Taiwan and once again triggered strong northeasterly winds. Figure 6 shows that the Daan/Dajia Rivers were affected by wind speeds close to $6 \mathrm{~m} \mathrm{~s}^{-1}$ and $7 \mathrm{~m} \mathrm{~s}^{-1}$ at noon time on 22 and 25 November, respectively. On the same days, the Dadu and Zhuoshui Rivers exceeded $4 \mathrm{~m} \mathrm{~s}^{-1}$ and $5 \mathrm{~m} \mathrm{~s}^{-1}$, respectively, while the Beinan River was about $3 \mathrm{~m} \mathrm{~s}^{-1}$ on both days. The wind direction was northeasterly in the Daan/Dajia Rivers, the same as in the typhoon type, but turned into northerly or northwesterly in the Dadu and Zhuoshui Rivers due to the eastward movement of the anticyclone and its interaction with the terrain. The northwesterly wind was seen in the Beinan River, but unlike the rivers in Central Taiwan, the local sea breeze from the south also prevailed during the daytime (Figure 6d). However, although the humidity of all rivers is approximately the same, only a significant increase in $\mathrm{PM}_{10}$ was observed on the Zhuoshui and Beinan Rivers. At noon time on 22 and 25 November, the hourly $\mathrm{PM}_{10}$ peak value of the Zhuoshui River reached about $400 \mathrm{\mu g} \mathrm{m}^{-3}$ (Figure 6c). During these stages, the $\mathrm{PM}_{2.5}$ and $\mathrm{PM}_{10}$ concentrations were not high in the riverside town and background Sanyi station, suggesting that the high value of suspended particles was mainly from riverbed dust. Similarly, on 25 November, $\mathrm{PM}_{10}$ concentration close to $200 \mu \mathrm{g} \mathrm{m}^{-3}$ was also observed on the Beinan River when the northeasterly wind prevailed (Figure 6d). Interestingly, the $\mathrm{PM}_{10}$ concentration in the riverside town reached $350 \mu \mathrm{g} \mathrm{m}^{-3}$, much higher than observed over the riverbed. Although the $\mathrm{PM}_{10}$ concentration in the Sanyi background station in Central Taiwan is low (less than $42 \mu \mathrm{g} \mathrm{m}^{-3}$ ), according to the EPA background station over the northeastern tip of Taiwan (Wanli Station), the maximum hourly $\mathrm{PM}_{10}$ concentration observed on that day was close to $140 \mathrm{\mu g} \mathrm{m}^{-3}$. Therefore, in addition to the dust generated from the riverbed, the $\mathrm{PM}_{10}$ in the riverside town of Beinan River may be partially affected by the long-range transport of coarse particles (such as Asian dust) due to its location over the southeastern coast and directly facing the northeasterly wind.

Late on 26 November, the center of the anticyclonic system left the coastal areas of China and passed over the marginal sea to the north of Taiwan (Figure 4d). Meteorological conditions had shifted to the stage of the behind anticyclonic system. The prevailing wind changed from northeasterly to easterly winds over northern Taiwan, and the wind speed also weakened (Figure 4d). At this stage, most of the riverbed areas were heavy polluted and the $\mathrm{PM}_{2.5}$ concentrations were high (Figure 6). At the same time, the $\mathrm{PM}_{10}$ at the Sanyi background station also reached more than $100 \mu \mathrm{g} \mathrm{m}^{-3}$, suggesting a high concentration of particles imported from abroad. In addition to the long-range transport, there were also a few cases of high dust concentration in riverbeds during the daytime. For example, at noon on 28 November, an hourly $\mathrm{PM}_{10}$ of $400 \mu \mathrm{g} \mathrm{m}^{-3}$ was observed over the Zhuoshui River. At the same time, the relative humidity was extremely low, reaching a minimum of around $40 \%$, and was favorable for riverbed emission under a maximum wind speed of $3.5 \mathrm{~m} \mathrm{~s}^{-1}$. At night, high concentrations of $\mathrm{PM}_{10}$ were also observed, especially in the Dadu River (Figure $6 \mathrm{~b}$ ). The land breeze from the east suggests that the high concentration of the river is related to the pollution of the main city in Central Taiwan (Taichung), which is located $10 \mathrm{~km}$ to the east of the river.

\subsection{Summary of Two Types}

Table 2 summarizes the times, peak $\mathrm{PM}_{10}$ concentrations, and the corresponding meteorological conditions at the peak concentration for each weather type in Table 1 . There are 6-11 cases for each type. One case in Table 2 represents one day listed in Table 1 . In Table 2, September and October are the months in which the typhoon type cases occurred (also see Table 1). Because there are more typhoon cases observed in October in the Zhuoshui River, they are listed as the main month and river in Table 2. The result in Table 2 
explains that in Figure $3 d$, the higher $\mathrm{PM}_{10}$ exceedance hours observed in October, especially in the Zhuoshui River, resulted from typhoons. In the non-typhoon type in Table 2, the riverbed events in ahead of front, ahead of anticyclone, and behind anticyclone stages were mainly observed in April, December, and both February and April, respectively. Riverbed events in these weather stages were mainly observed in the Zhuoshui and Dadu Rivers.

Table 2. Summary of the aerosol and weather conditions for riverbed events in Table 1, including number of cases, main month and river of the weather type, time of peak concentration, mean peak $\mathrm{PM}_{10}$ concentrations, and mean $\mathrm{PM}_{2.5}$ concentrations in town, mean peak $\mathrm{PM}_{10}$ concentrations in Sanyi background station, mean wind speed (WS), percentage of wind direction (WD), mean temperature $(\mathrm{T})$, and mean relative humidity $(\mathrm{RH})$ at peak $\mathrm{PM}_{10}$ concentrations.

\begin{tabular}{|c|c|c|c|c|c|c|c|c|c|c|c|}
\hline \multicolumn{2}{|c|}{ Types } & $\begin{array}{l}\text { \# of } \\
\text { Case }\end{array}$ & $\begin{array}{c}\text { Main } \\
\text { Month/River }\end{array}$ & $\begin{array}{c}\text { Time of Peak } \\
\mathrm{PM}_{10} \\
\left(\mu \mathrm{g} \mathrm{m}^{-3}\right)\end{array}$ & $\begin{array}{c}\text { Peak } \\
\text { PM }_{10} \\
\left(\mu \mathrm{g} \mathrm{m}^{-3}\right)\end{array}$ & $\begin{array}{c}\mathrm{PM}_{2.5} \text { in } \\
\text { Town } \\
\left(\mu \mathrm{g} \mathrm{m}^{-3}\right)\end{array}$ & $\begin{array}{c}\text { Sanyi } \\
\mathrm{PM}_{10} \\
\left(\mu \mathrm{g} \mathrm{m}^{-3}\right)\end{array}$ & $\begin{array}{l}\text { WS } \\
(\mathrm{m} \\
\left.\mathrm{s}^{-1}\right)\end{array}$ & $\begin{array}{l}\text { WD } \\
(\%)\end{array}$ & $\begin{array}{c}\mathrm{T} \\
\left({ }^{\circ} \mathrm{C}\right)\end{array}$ & $\begin{array}{l}\mathrm{RH} \\
(\%)\end{array}$ \\
\hline \multicolumn{2}{|c|}{ Typhoon } & 9 & $\begin{array}{l}\text { October/ } \\
\text { Zhuoshui }\end{array}$ & $\begin{array}{c}\text { morning } \\
\text { noon }\end{array}$ & 626 & 37 & 62 & 6.5 & $\begin{array}{l}\text { NE:89 } \\
\text { NW:11 }\end{array}$ & 25 & 60 \\
\hline \multirow[t]{3}{*}{$\begin{array}{l}\text { Non- } \\
\text { Typhoon }\end{array}$} & $\begin{array}{l}\text { Ahead of } \\
\text { Front }\end{array}$ & 6 & $\begin{array}{c}\text { April/ } \\
\text { Dadu, } \\
\text { Zhuoshui }\end{array}$ & $\begin{array}{l}\text { morning } \\
\text { noon } \\
\text { night }\end{array}$ & 272 & 128 & 145 & 1.4 & $\begin{array}{c}\text { NW:66 } \\
\text { SE:17 } \\
\text { NE:17 }\end{array}$ & 23 & 78 \\
\hline & $\begin{array}{c}\text { Ahead of } \\
\text { Anticyclone }\end{array}$ & 6 & $\begin{array}{l}\text { December/ } \\
\text { Zhuoshui }\end{array}$ & daytime & 428 & 64 & 62 & 5.2 & $\begin{array}{l}\text { NE:50 } \\
\text { NW:50 }\end{array}$ & 20 & 60 \\
\hline & $\begin{array}{c}\text { Behind } \\
\text { Anticyclone }\end{array}$ & 11 & $\begin{array}{c}\text { February, } \\
\text { April/ } \\
\text { Dadu }\end{array}$ & $\begin{array}{c}\text { morning } \\
\text { night }\end{array}$ & 301 & 132 & 147 & 0.7 & $\begin{array}{c}\text { NE:55 } \\
\text { SE:27 } \\
\text { NW:18 }\end{array}$ & 19 & 79 \\
\hline
\end{tabular}

In addition, Table 2 shows the time of peak $\mathrm{PM}_{10}$ concentration for each type. We roughly classified the time of day as morning (06:00-09:00 local time), noon time (10:00-15:00 local time), afternoon (16:00-17:00), and night (18:00-05:00). Although more peak concentrations of riverbed events were observed at noon time from 11:00 to 15:00, peak concentrations were also observed in the morning in the typhoon type. For example, on the Daan/Dajia and Zhuoshui Rivers, a typhoon type on 28 September 2012 was observed at 8:00-9:00 a.m. The occurrence time of the typhoon type is similar to that in the ahead of anticyclone stage, except that the peak time of the ahead of anticyclone stage appears to be more extended, and was observed from 09:00 to 15:00 during the day. These two types also explain that the high concentrations of $\mathrm{PM}_{10}$ in Figure 3e appeared at noon time and a few in the morning. Different from these two types, in the ahead of front stage, peak $\mathrm{PM}_{10}$ concentration appeared throughout the day, while in the behind anticyclone stage, peak $\mathrm{PM}_{10}$ concentration was only observed in the morning and at night. Thus, the peak $\mathrm{PM}_{10}$ concentrations in these two stages resulted from different mechanisms.

Table 2 also lists the average concentration of the peak $\mathrm{PM}_{10}$ in the riverbed, peak $\mathrm{PM}_{2.5}$ of the riverside town, and peak $\mathrm{PM}_{10}$ concentration of the day at the Sanyi background station for each weather type. Among them, the peak $\mathrm{PM}_{10}$ concentration in the riverbed caused by the typhoon types exceeded $600 \mu \mathrm{g} \mathrm{m}^{-3}$ on average, which is the highest concentration of all types. The ahead of anticyclone stage of the non-typhoon type exceeding $400 \mu \mathrm{g} \mathrm{m}^{-3}$ is the second highest concentration. In addition, the $\mathrm{PM}_{2.5}$ concentration of these two types is low, with an average of 37 to $64 \mu \mathrm{g} \mathrm{m}^{-3}$, respectively, indicating that the concentration of pollutants from either local areas or imported is low. Furthermore, during these two types of events, the highest concentration of $\mathrm{PM}_{10}$ at the Sanyi background station in Central Taiwan is about $60 \mu \mathrm{g} \mathrm{m}^{-3}$, implying that the contribution from Asian dust was low. Therefore, the high riverbed $\mathrm{PM}_{10}$ concentrations of these two types is mainly caused by the riverbed dust generation. On the contrary, the $\mathrm{PM}_{10}$ in the ahead of front and behind anticyclone stages in the non-typhoon types are both around $300 \mu \mathrm{g} \mathrm{m}^{-3}$ on average, but their $\mathrm{PM}_{2.5}$ concentration is higher, both being about $130 \mu \mathrm{g} \mathrm{m}^{-3}$, indicating that part of the riverbed aerosol may come from pollution rather than riverbed emission. Also, the background $\mathrm{PM}_{10}$ concentration at Sanyi is close to $150 \mu \mathrm{g} \mathrm{m}^{-3}$ on average, indicating that the pollution from the Asian continent contributes a lot during these two weather stages. 
The influence of the surface wind speed and wind direction on riverbed dust generation is also shown in Table 2. At the peak $\mathrm{PM}_{10}$ concentrations of the typhoon type, the surface wind speeds reach an average value of $6.5 \mathrm{~m} \mathrm{~s}^{-1}$, while more than $5 \mathrm{~m} \mathrm{~s}^{-1}$ in the ahead of anticyclone stage, and thus high wind speed is critical for riverbed dust generation. In the typhoon type, the wind directions are mostly northeasterly winds, but in the ahead of anticyclone type, only half of the wind directions are northeasterly winds, and the other half are northwesterly winds. Similarly, Tsai et al. [36] also reported that after a frontal passage over Taiwan, the wind direction changes from northwesterly to northeasterly in Northern Taiwan. In contrast to these two types, the averaged wind speeds in the stages of ahead of front and behind anticyclone are lower, with only $1 \mathrm{~m} \mathrm{~s}^{-1}$ of average wind speed. In addition, the wind directions of these two types are more diversified, and northeasterlies, northwesterlies, and southeasterlies were all observed in both types at the peak $\mathrm{PM}_{10}$ concentrations. Among them, northwesterly is the main wind direction in the ahead of front stage of the non-typhoon type. As discussed in the case study, most of it is related to the sea breeze during the day and the cyclonic circulation, and the wind direction may carry pollutants to the riverbeds. The southeasterlies in the two stages are mostly observed in the Dadu River. As discussed in Section 4.2, the main city in Central Taiwan is located to the east of the river, and the land breeze can carry pollutants to affect the concentration of the river. Northeasterly is the main wind direction for the behind anticyclone stage. The high concentrations of $\mathrm{PM}_{2.5}$ at the riverside town and $\mathrm{PM}_{10}$ at the background station show that the riverbed is affected by local pollution and foreign aerosol at this time. This is because during the winter monsoon, northeasterly winds can bring pollution from Asia, resulting in high background pollution in Taiwan. Liu et al. [23] and Hung et al. [26] also showed that due to the long-range transport of dust or pollutant from the Asian continent, the averaged background concentration of $\mathrm{PM}_{10}$ in Northern Taiwan can be as high as $100 \mu \mathrm{g} \mathrm{m}^{-3}$ during the event, and April is the month with the highest background concentration. Our results are consistent with those studies.

The average temperature and relative humidity in Table 2 also give an explanation for the high $\mathrm{PM}_{10}$ concentration in the riverbeds. The typhoon type has the highest average temperature $\left(25^{\circ} \mathrm{C}\right)$, and the weather is usually warm and humid. However, this type of low relative humidity also shows that the moist air has not reached Central Taiwan, where most of the rivers are located, so it is conducive to dust emissions. For the ahead of anticyclone type, the temperature is lower $\left(20^{\circ} \mathrm{C}\right)$, but the dry air (mean humidity of $60 \%$ ) is also favorable for riverbed emissions. In contrast, the behind anticyclone and ahead of front stages in the non-typhoon types both have high humidity close to $80 \%$. Particularly for the behind anticyclone stage, the cold and humid air is not favorable for dust emission, and thus the riverbed events were significantly affected by local pollutant or foreign aerosol.

\subsection{Monthly and Hourly Mean Meteorology}

Table 2 shows that the riverbed events were mainly observed during different weather stages in December, February, and April, respectively, and also often observed at noon time. To further explain the high riverbed $\mathrm{PM}_{10}$ concentrations observed in these months rather than in the same weather stages of other months and times, the monthly and hourly mean wind speed, temperature, relative humidity, and precipitations of all the rivers are plotted and the general meteorological conditions are discussed (Figure 7). Figure 7a shows that during the winter monsoon from October to April, higher monthly average wind speeds were observed in all the rivers than in the summer monsoon. In addition, the peak monthly wind speeds were observed from December to February. Thus, during the ahead of anticyclone stage of these months, the strong wind speeds can result in higher riverbed emission compared to other months. In contrast, April is at the end of winter monsoon. The wind speed decreases (Figure 7a) and thus the weak wind speed behind the anticyclone can easily result in the accumulation of local pollution compared to other months, and enhance the riverbed concentration. In addition, a previous study [23] also found that in December and April, the amount of Asian dust transported to Northern Taiwan was higher 
than in other months. Under high background concentration, more riverbed events can also be observed. However, January is the month with the lowest riverbed concentration (Figure 3), despite the maximum wind speed of the months. It is possible that due to the low temperature in January (Figure $7 \mathrm{~b}$ ), Asian deserts are easily covered by snow, resulting in the reduction of Asian dust emissions and transport. The low foreign dust concentration in this month also resulted in the lower $\mathrm{PM}_{10}$ concentration in the riverbed areas. The similar low $\mathrm{PM}_{10}$ concentration is also seen in a previous study of Northern Taiwan [23].
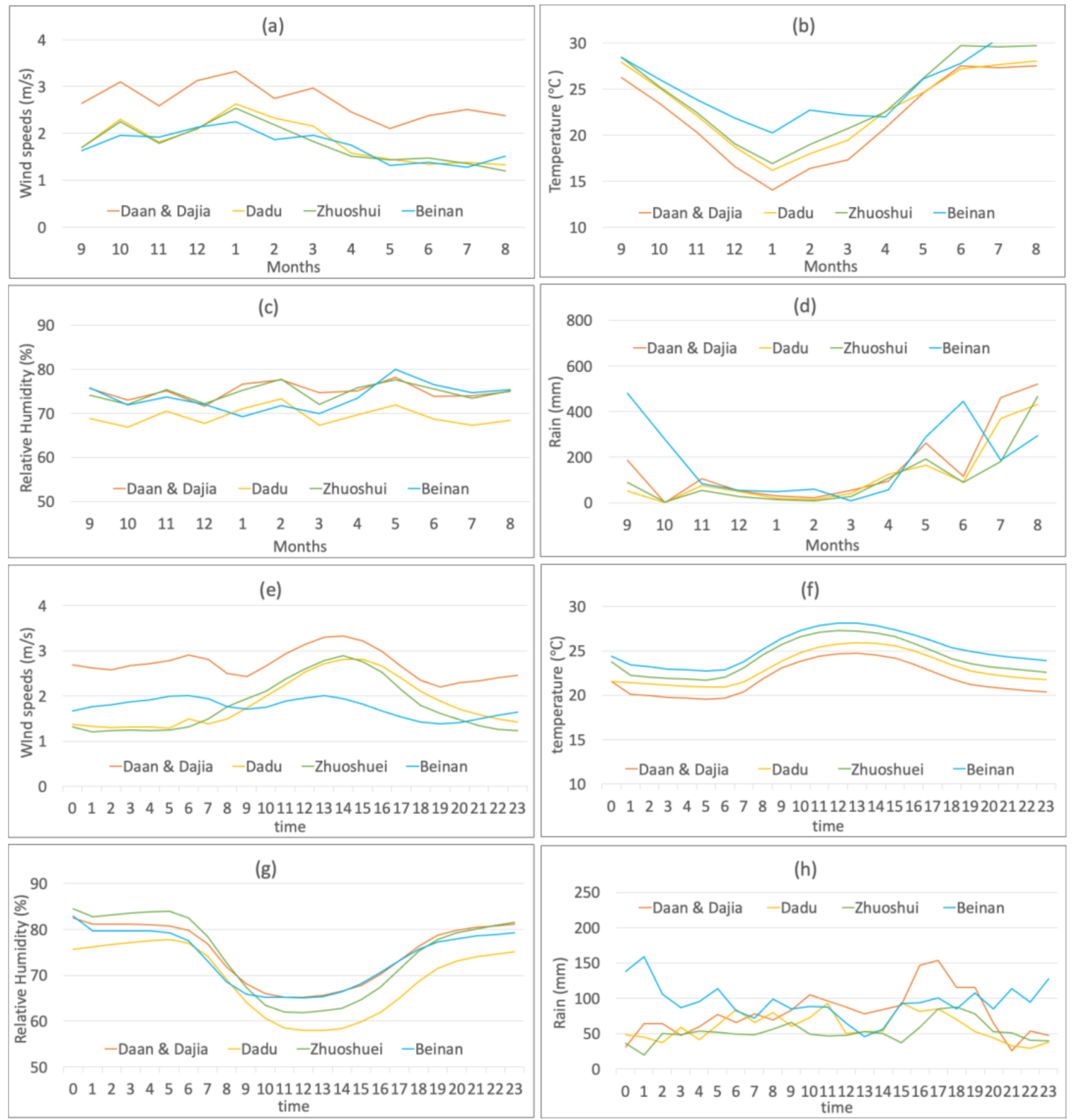

Figure 7. Monthly and hourly mean $(\mathbf{a}, \mathbf{e})$ wind speeds, $(\mathbf{b}, \mathbf{f})$ temperatures, and $(\mathbf{c}, \mathbf{g})$ relative humidity obtained from riverbed monitoring stations, and $(\mathbf{d}, \mathbf{h})$ rainfall amounts obtained from the closest EPA monitoring stations adjacent to each of the riverbed stations.

In addition, Figure 7c shows that the monthly average relative humidity is around 70\% for all the rivers, and Figure $7 d$ shows that rainfall in all the rivers during the winter monsoon is extremely low, different from that during the summer monsoon (May to September). The dry condition is favorable for riverbed dust generation during those months.

The average meteorological values in a day (Figure 7e-h) show that higher wind speeds often occur around noon for all the rivers, and the maximum wind speed is between 13:00-14:00. The highest temperature was also observed at noon, while the hourly average relative humidity of all rivers reaches a minimum at noon time. The strong wind speed, 
high temperature, and low humidity at noon time are conducive to dust emission from the riverbed, as shown in Table 2. Furthermore, the hourly average rainfall in Figure $7 \mathrm{~h}$ shows that the 24-h rainfall of all rivers remains mostly around $50 \mathrm{~mm}$ to $100 \mathrm{~mm}$. Among them, the minimum mean precipitation was observed over the Zhuoshui River most of the time, which may be one of the reasons for the high riverbed $\mathrm{PM}_{10}$ concentration shown in Figure 3.

\section{Conclusions}

This study analyzed the monitoring data from the main riverbed stations of Taiwan for two years. The monitored data include the hourly $\mathrm{PM}_{10}$ concentrations and meteorological conditions of the Daan, Dajia, Dadu, Zhuoshui, and Beinan Rivers. The results show that the $\mathrm{PM}_{10}$ concentrations in the riverbeds are higher during the winter monsoon than in the summer monsoon. Among these rivers, the $\mathrm{PM}_{10}$ concentration in Daan/Dajia and Zhuoshui Rivers reached $800 \mu \mathrm{g} \mathrm{m}^{-3}$ for $1-3 \mathrm{~h}$ a year, and in all rivers reached $125 \mu \mathrm{g} \mathrm{m}^{-3}$ for $35-465 \mathrm{~h}$ a year. However, the $\mathrm{PM}_{10}$ concentration of the riverbed at other times is low and the riverbed dust generation is sporadic. Thus, the monthly variations of $\mathrm{PM}_{10}$ concentration in these riverbeds are large. The ratio of the maximum to the minimum monthly average of each riverbed is about threefold, which shows that the dust from the riverbed has a certain contribution during the winter monsoon months. Among them, October, December, February, and April are the months with higher $\mathrm{PM}_{10}$ levels in these rivers, and most of the riverbed high concentrations occur at noon time, but the Dadu River has a high concentration in the morning. In addition, the main wind directions that cause high concentrations in the riverbed are northeasterly and northwesterly, which account for at least $70 \%$ of the wind direction, while meteorological factors such as wind speed, temperature, and humidity vary greatly at the high concentrations.

To explain these characteristics, we classified the weather conditions of the highconcentration cases whose daily average $\mathrm{PM}_{10}$ exceeds the air quality standard of $125 \mu \mathrm{g} \mathrm{m}$ into typhoon and non-typhoon. For non-typhoon types, we further divided the types into ahead of front, ahead of anticyclone, and behind anticyclone stages to examine the effects of the meteorological conditions on high $\mathrm{PM}_{10}$ concentrations. Two events with and without typhoon are taken as examples to illustrate the impact of weather conditions and the corresponding meteorological factors on the high concentrations in the riverbed.

The results show that the extremely high $\mathrm{PM}_{10}$ values on the riverbeds are caused by the typhoon types and the ahead of anticyclone stage in the non-typhoon types. The highest concentration of $\mathrm{PM}_{10}$ of the two types is as high as $600 \mu \mathrm{g} \mathrm{m}^{-3}$ and $400 \mu \mathrm{g} \mathrm{m}^{-3}$ on average, and the averaged wind speeds are above 6 and $5 \mathrm{~m} \mathrm{~s}^{-1}$ for the two types, respectively. The typhoon-type riverbed events mainly occur in October, and the ahead of anticyclone events mainly occur in December. The monthly mean meteorological conditions shows that the wind speed is stronger in the beginning of winter monsoon months, such as December, which is beneficial for the riverbed dust emission during the ahead of anticyclone stage. In the daytime, especially at noon time, is the time period when peak $\mathrm{PM}_{10}$ concentration of these two types is observed in the riverbeds. In addition, these two types have low pollutant concentrations, and the background $\mathrm{PM}_{10}$ value in Central Taiwan is also about $60 \mu \mathrm{g} \mathrm{m}^{-3}$, indicating that the high concentrations are mainly caused by riverbed dust generation. Comparing the typhoon type and the ahead of anticyclone type riverbed events, the typhoon type has stronger wind speed, and the wind direction is almost northeasterly, while in the ahead of anticyclone type, both northeasterly and northwesterly winds account for half of the percentage. The typhoon types have a high average temperature of $25^{\circ} \mathrm{C}$, while the ahead of anticyclone type has a lower temperature of $20^{\circ} \mathrm{C}$, but the same dry air with an average humidity of $60 \%$ is conducive to riverbed dust generation.

On the other hand, the main months of high daily $\mathrm{PM}_{10}$ concentration for the ahead of front and behind the anticyclone stages in the non-typhoon types are February and April. In the ahead of front stage, high $\mathrm{PM}_{10}$ concentration was observed throughout the day in the riverbeds, while the behind the anticyclone stage did not observe the high concentration 
at noon time. Both types of peak $\mathrm{PM}_{10}$ concentration are about $300 \mu \mathrm{g} \mathrm{m}^{-3}$, and their $\mathrm{PM}_{2.5}$ concentrations are also high, and are about $130 \mu \mathrm{g} \mathrm{m}^{-3}$, indicating that part of the riverbed events are caused by pollution, not riverbed emissions. In addition, the $\mathrm{PM}_{10}$ concentration at the background station is close to around $150 \mu \mathrm{g} \mathrm{m}^{-3}$, indicating that the aerosol from the Asian continent has contributed to the high concentration in the riverbeds. Furthermore, the average wind speeds of the ahead of front and behind anticyclone stages are relatively low, and both are only around $1 \mathrm{~m} \mathrm{~s}^{-1}$ on average over the riverbeds. The weak wind speed of these weather stages can result in accumulation of local pollution, and affect the riverbed areas. The wind directions of these two types are also more diversified, and northeasterly, northwesterly, and southeasterly winds are observed in both types at the peak of $\mathrm{PM}_{10}$ concentration. In addition, the two stages both have high humidity close to $80 \%$, which is not conducive to riverbed dust emission. However, a small number of strong winds in these stages was observed to cause dust emission, although the riverbed event is significantly affected by local pollutants and foreign aerosol.

Supplementary Materials: The following are available online at https:/ /www.mdpi.com/article/ 10.3390/atmos13010106/s1, Figure S1: Satellite image of $\mathrm{PM}_{2.5}$ and aerosol optical depth on 21 November 2010, showing high concentration of pollutant over central western Taiwan and the marginal sea.

Author Contributions: Conceptualization, methodology, validation, writing—original draft preparation, writing - review and editing, supervision, F.T.; formal analysis, W.-C.Y.; investigation, M.-L.L. All authors have read and agreed to the published version of the manuscript.

Funding: This work is supported by the Ministry of Science and Technology in Taiwan under the project of MOST 107-2111-M-019-002-

Institutional Review Board Statement: Not applicable.

Informed Consent Statement: Not applicable.

Data Availability Statement: https://data.epa.gov.tw/zh_TW/dataset/aqx_p_04, accessed on 4 January 2022.

Acknowledgments: The authors gratefully acknowledge the Taiwan Environmental Protection Administration for providing the monitoring data for use in this publication. We also thank the National Centers for Environmental Prediction for providing global reanalysis data for weather analysis, and the NASA's Earthdata Support group for providing the Worldview image of particulate matter and aerosol optical depth for our use.

Conflicts of Interest: The authors declare no conflict of interest.

\section{References}

1. Wang, W.; Huang, J.; Minnis, P.; Hu, Y.; Li, J.; Huang, Z.; Ayers, J.K.; Wang, T. Dusty cloud properties and radiative forcing over dust source and downwind regions derived from A-Train data during the Pacific Dust Experiment. J. Geophys. Res. Atmos. 2010, 115, D4. [CrossRef]

2. Chen, S.; Huang, J.; Kang, L.; Wang, H.; Ma, X.; He, Y.; Yuan, T.; Yang, B.; Huang, Z.; Zhang, G. Emission, transport, and radiative effects of mineral dust from the Taklimakan and Gobi deserts: Comparison of measurements and model results. Atmos. Chem. Phys. 2017, 17, 2401-2421. [CrossRef]

3. Zhou, T.; Xie, H.; Bi, J.; Huang, Z.; Huang, J.; Shi, J.; Zhang, B.; Zhang, W. Lidar Measurements of Dust Aerosols during Three Field Campaigns in 2010, 2011 and 2012 over Northwestern China. Atmosphere 2018, 9, 173. [CrossRef]

4. Zhou, T.; Xie, H.; Jiang, T.; Huang, J.; Bi, J.; Huang, Z.; Shi, J. Seasonal characteristics of aerosol vertical structure and autumn enhancement of non-spherical particle over the semi-arid region of northwest China. Atmos. Environ. 2021, 244, 117912. [CrossRef]

5. Charlson, R.J.; Schwartz, S.E.; Hales, J.M.; Cess, R.D.; Coakley, J.A.; Hansen, J.E.; Hofmann, D.J. Climate forcing by anthropogenic aerosols. Science 1992, 255, 423-430. [CrossRef]

6. Sokolik, I.N.; Toon, O.B. Direct radiative forcing by anthropogenic airborne mineral aerosols. Nature 1996, 381, 681-683. [CrossRef]

7. Ramanathan, V.C.P.J.; Crutzen, P.J.; Kiehl, J.T.; Rosenfeld, D. Aerosols, climate, and the hydrological cycle. Science 2001, 294, 2119-2124. [CrossRef]

8. Kaufman, Y.J.; Tanre, D.; Boucher, O.A. Satellite view of aerosols in the climate system. Nature 2002, 419, 215-223. [CrossRef]

9. DeMott, P.J.; Sassen, K.; Poellot, M.R.; Baumgardner, D.; Rogers, D.C.; Brooks, S.D.; Prenni, A.J;; Kreidenweis, S.M. African dust aerosols as atmospheric ice nuclei. Geophys. Res. Lett. 2003, 30, 1732. [CrossRef] 
10. Huebert, B.J.; Bates, T.; Russell, P.B.; Shi, G.Y.; Kim, Y.J.; Kawamura, K.; Carmichael, G.; Nakajima, T. An overview of ACE-Asia: Strategies for quantifying the relationships between Asian aerosols and their climatic impacts. J. Geophys. Res. 2003, 108, D23.

11. Vickery, K.J.; Eckardt, F.D. Dust emission controls on the lower Kuiseb River valley, Central Namib. Aeolian Res. 2013, 10, 125-133 [CrossRef]

12. Dansie, A.P.; Wiggs, G.F.S.; Thomas, D.S.G.; Washington, R. Measurements of windblown dust characteristics and ocean fertilization potential: The ephemeral river valleys of Namibia. Aeolian Res. 2017, 29, 30-41. [CrossRef]

13. Von Holdt, J.R.; Eckardt, F.D. Dust activity and surface sediment characteristics of the dustiest river in southern Africa: The Kuiseb River, Central Namib. South Afr. Geogr. J. 2018, 100, 104-121. [CrossRef]

14. Lin, C.W.; Yeh, J.F. Estimating dust emission from a sandbank on the downstream Jhuoshuei River under strong wind conditions. Atmos. Environ. 2007, 41, 7553-7561. [CrossRef]

15. Kuo, S.C.; Hsieh, L.Y.; Tsai, C.H.; Tsai, Y.I. Characterization of PM2.5 fugitive metal in the workplaces and the surrounding environment of a secondary aluminum smelter. Atmos. Environ. 2007, 41, 6884-6900. [CrossRef]

16. Lin, C.Y.; Tsai, S.F.; Chuang, C.W. Delineation and management of dust emission potential areas on riverbed. J. Chin. Soil Water Conserv. 2008, 39, 367-377.

17. Bachmeier, A.S.; Newell, R.E.; Shipham, M.C.; Zhu, Y.; Blake, D.R.; Browell, E.V. PEM-West A: Meteorological overview. J Geophys. Res. 1996, 101, 1655-1677. [CrossRef]

18. Water Resources Agency, Taiwan. (in Chinese). Available online: https:/ /www.wra.gov.tw/cl.aspx?n=3270. (accessed on 4 January 2021).

19. Shih, T.T.; Chang, J.C.; Lin, H.M. A geomorphological study on the estuaries in northern Taiwan. Geogr. Res. 1996, $26,1-38$.

20. Liang, S.; Wang, Y.J.; Tzou, W.J. A study on utilization mechanism for unsubmerged lands along river channels during low flows. J. Soil Water Conserv. 1999, 31, 123-137.

21. Environmental Protection Administration. Evaluation of Aeolian Dust from Rivers on the Aerosol in Central Taiwan; EPA-097-fa14-03a042; The Research Project of Environmental Protection Administration: Taipei, Taiwan, 2009. (In Chinese)

22. Environmental Protection Administration, Taiwan. Available online: https://airtw.epa.gov.tw/ENG/TaskMonitoring/ RiverDust/RiverDustIntro.aspx. (accessed on 4 January 2021).

23. Liu, T.H.; Tsai, F.; Hsu, S.C.; Hsu, C.W.; Shiu, C.J.; Chen, W.N.; Tu, J.Y. Southeastward transport of Asian dust: Source, transport and its contributions to Taiwan. Atmos. Environ. 2009, 43, 458-467. [CrossRef]

24. Tsai, F.J.; Fang, Y.S.; Huang, S.J. Case Study of Asian Dust Event on March 19-25, 2010 and Its Impact on the Marginal Sea of China. J. Mar. Sci. Technol. 2013, 21, 353-360.

25. Tsai, F. Model simulation of Asian dust and iron depositions over the East Asian marginal seas. J. Mar. Sci. Technol. 2013, 21, 460-468.

26. Hung, W.T.; Lu, C.H.S.; Wang, S.H.; Chen, S.P.; Tsai, F.; Chou, C.C.K. Investigation of long-range transported PM2.5 events over Northern Taiwan during 2005-2015 winter seasons. Atmos. Environ. 2019, 217, 116920. [CrossRef]

27. Lin, C.W.; Yeh, J.F.; Kao, T.C. Source characterization of total suspended particulate matter near a riverbed in Central Taiwan. J. Hazard. Mater. 2008, 157, 418-422. [CrossRef]

28. Kuo, C.Y.; Lin, C.Y.; Huang, L.M.; Wang, S.; Shieh, P.F.; Lin, Y.R.; Wang, J.Y. Spatial variations of the aerosols in river-dust episodes in central Taiwan. J. Hazard. Mater. 2010, 179, 1022-1030. [CrossRef]

29. Kuo, C.Y.; Yang, H.J.; Chiang, Y.C.; Lai, D.J.; Shen, Y.H.; Liu, P.M. Concentration and composition variations of metals in the outdoor PM 10 of elementary schools during river dust episodes. Environ. Sci. Pollut. Res. 2014, 21, 12354-12363. [CrossRef]

30. Kuo, C.Y.; Hsieh, C.Y.; Hu, C.W.; Chen, S.C.; Yang, H.J. PM10 concentration in relation to clinic visits for anxiety disorders: A population-based study of a high river-dust episode region in Taiwan. Air Qual. Atmos. Health 2018, 11, 221-227. [CrossRef]

31. Syu, J.Y.; Cheng, Y.C.; Kao, Y.Y.; Liang, C.S.; Yan, Y.L.; Lai, C.Y.; Chang, C.T.; Chen, C.C.; Young, C.Y.; Wu, Y.L.; et al. The horizontal and vertical characteristics of Aeolian dust from riverbed. Aerosol Air Qual. Res. 2016, 16, 3026-3036. [CrossRef]

32. Chiang, Y.C.; Yang, H.J.; Chen, S.C.; Hu, C.W.; Tsai, C.T.; Lai, D.J.; Kuo, C.Y. Inhalation exposure of children to indoor PM 10 and associated metals during river-dust episodes. Air Qual. Atmos. Health 2017, 10, 381-388. [CrossRef]

33. Giri, D.; Adhikary, P.R.; Murthy, V.K. The influence of meteorological conditions on PM10 concentrations in Kathmandu Valley. Int. J. Environ. Res. 2008, 2, 49-60.

34. Nguyen, M.V.; Park, G.H.; Lee, B.K. Correlation analysis of size-resolved airborne particulate matter with classified meteorological conditions. Meteorol. Atmos. Phys. 2017, 129, 35-46. [CrossRef]

35. Wei, P.; Cheng, S.; Li, J.; Su, F. Impact of boundary-layer anticyclonic weather system on regional air quality. Atmos. Environ. 2011, 45, 2453-2463. [CrossRef]

36. Tsai, F.; Liu, T.H. Modeling study of three consecutive high ozone episodes over Taiwan in spring 2007. Atmos. Environ. 2013, 80, 131-139. [CrossRef] 